\author{
A.S. Kishkentayeva, S.N. Mantler*, M.M. Zhakanov, S.M. Adekenov \\ JSC "International Research and Production Holding "Phytochemistry", Karaganda, Kazakhstan \\ (Corresponding author's e-mail: s.mantler@phyto.kz)
}

\title{
Biologically active substances from Achillea nobilis L.
}

\begin{abstract}
The review summarizes data on biologically active compounds of Achillea nobilis L. and methods of their isolation. From Achillea nobilis L., collected in different places of growth, the following have been isolated: essential oil, the main components of which are monoterpene compounds; sesquiterpene lactones estafiatin, hanphyllin, anobin, chrysartemine A, canin, anolide and tanapartin- $\beta$-peroxide; the steroid acetyleucanbin; flavonoids: 3,5-dihydroxy-6,7,8-trimethoxyflavone, 5-hydroxy-3,6,7,4'-tetramethoxyflavone and 5,3'-dihydroxy-3,6,7,4'-tetramethoxyflavone. It has been determined that the component composition of the essential oil of Achillea nobilis L. largely depends on the soil and climatic factors in the places of its growth, the phase of the growing season and the method of its extraction from plant raw materials, and the extractant used (chloroform, ethanol, hot water, diethyl ether). Antibacterial, antimicrobial, antioxidant, antiparasitic activities are characteristic both for the sums of extractive substances from Achillea nobilis L. and for individual compounds isolated from them. Methods for the isolation of biologically active substances from Achillea nobilis L. for the development of new drug substances are described. The main aim of this work was a comparative analysis of the available research results on the phytochemical study of Achillea nobilis $\mathrm{L}$.
\end{abstract}

Keywords: Asteraceae, Achillea nobilis L., sesquiterpene lactones, essential oil, flavonoids, isolation methods, biological activity.

\section{Introduction}

Plants of the genus Achillea L. of the Asteraceae family are considered as a promising source of biologically active substances, among which the most important are terpenoids and phenolic compounds. Other classes of natural compounds are also isolated from Achillea L.: carbohydrates (inulin and other polysaccharides, rhamnose, arabinose, xylose, mannose, glucose, galactose), bitter principles and tannins, microelements, acids (ascorbic, malic, aconitic, caffeic), amino acids, vitamins, alkaloids (achillein), coumarins (umbelliferone, scopoletin, isoscopoletin, scoparone and isofraxidine) [1, 2]. Essential oil of Achillea L. species is a source of proazulenes and azulenes [3].

Preparations based on Achillea L. are widely used in medical practice. They have a hemostatic, bactericidal, anti-inflammatory, wound-healing, anticonvulsant, anti-allergic effect, improve digestion, expand bile ducts, and increase bile secretion [4]. Achillea millefolium L. is among the top five plants containing the largest number of anthelmintic compounds, along with Rosmarinus officinalis L. and Salvia officinalis L. [5]. The results of studies of the anthelmintic efficacy of Achillea millefolium L. herb, carried out on experimental groups of birds (geese and ducks), showed the possibility of its use against helminthiasis of domestic waterfowl [2]. In work [6], the aqueous extract of Achillea millefolium L. (flowers) and a number of other plants were tested in vitro, and their ovicidal and larvicidal activity against nematodes in animals was confirmed.

The above-said indicates that it is promising to search among the secondary metabolites of plants of the genus Achillea L. for compounds responsible for their anthelmintic activity.

The main aim of this work was a comparative analysis of the available research results on the phytochemical study of Achillea nobilis L.

\section{Main part}

Over 10 species of plants of the genus Achillea L. grow on the territory of Kazakhstan. The most widespread among them are A. asiatica Serg., A. setacea Waldst. et Kit., A. millefolium L., A. nobilis L., A. micrantha Willd., A. salicifolia Bess., A. cartilaginea Ldb. [7]. Many taxa of this group are very similar in morphological characters and it is difficult to differentiate them without special morphological knowledge.

\footnotetext{
${ }^{*}$ Corresponding author.
} 
There is an accessible exploitable raw material stock of $A$. nobilis L. on the territory of Central Kazakhstan, which is used in folk medicine as a phylogenetically close species to the officinal and relatively wellstudied A. millefolium L. It is distributed over high meadow and shrub steppes, on hillsides and river valleys [7].

According to the literature data, essential oil, the main components of which are monoterpene compounds; sesquiterpene lactones: estafiatin (1), hanphyllin (2), anobin (3), chrysartemine A (4), canin (5), anolide (6) and tanapartin- $\beta$-peroxide (7); steroid acetyleucanbin (8); flavonoids: 3,5 -dihydroxy-6,7,8trimethoxyflavone (9), 5-hydroxy-3,6,7,4'-tetramethoxyflavone (10), 5,3'-dihydroxy-3,6,7,4'-tetramethoxyflavone (11) [8-12] were isolated from A. nobilis L., collected in different places of growth (Table).<smiles>C=C1CC[C@H]2C(=C)C(=O)O[C@@H]2C2C1CC1O[C@@]12C</smiles>

(1)

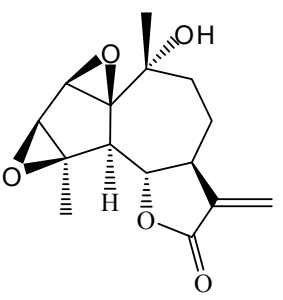

(5)<smiles>COc1c(OC)c(O)c2c(=O)c(O)c(-c3ccccc3)oc2c1OC</smiles>

(9)<smiles>C=C1C(=O)O[C@@H](/C=C(\C)CC/C=C\C)[C@@H]1O</smiles>

(2)<smiles>C=C1CC[C@@H]2C(=C)C(=O)O[C@@H]2[C@@H]2[C@@H]1C[C@H](O)C2(O)O</smiles>

(6)<smiles>COc1ccc(-c2oc3cc(OC)c(OC)c(O)c3c(=O)c2OC)cc1</smiles>

(10)<smiles>C=C1C(=O)O[C@H]2[C@@H]1CC[C@](C)(O)[C@@]13C=C[C@@](C)(O1)[C@]23C</smiles>

(7)<smiles>C=C1C(=O)O[C@H]2C3C([C@]4(C)O[C@@H]34)[C@](C)(O)CC[C@@H]12</smiles>

(3)<smiles>C=C1C(=O)O[C@H]2[C@@H]1CC[C@@]1(C)O[C@]13OC2(C)[C@@H]1O[C@H]13</smiles>

(4)<smiles>C=C(CCC(C)(C)C(C)C)C1CC[C@H]2[C@@H]3CCC4C[C@@H](OC(C)=O)CC[C@]4(C)[C@H]3CC[C@]12C</smiles>

(8)<smiles>COc1ccc(-c2oc3cc(OC)c(OC)c(O)c3c(=O)c2OC)cc1O</smiles>

(11)

$\mathrm{T}$ a b l e

Compounds isolated from Achillea nobilis $\mathrm{L}$.

\begin{tabular}{|c|c|c|c|c|}
\hline Name of compound & Gross formula & State of substance & $\begin{array}{c}\text { Melting } \\
\text { temperature, }{ }^{\circ} \mathrm{C}\end{array}$ & Ref. \\
\hline Estafiatin (1) & $\mathrm{C}_{15} \mathrm{H}_{18} \mathrm{O}_{3}$ & Colorless acerous crystals & $102-104$ & [8] \\
\hline Hanphyllin (2) & $\mathrm{C}_{15} \mathrm{H}_{20} \mathrm{O}_{3}$ & Colorless lamellar crystals & 189 & [8] \\
\hline Anobin (3) & $\mathrm{C}_{15} \mathrm{H}_{20} \mathrm{O}_{5}$ & Colorless rhombic crystals & $175.5-177.5$ & [8] \\
\hline Chrysartemine A (4) & $\mathrm{C}_{15} \mathrm{H}_{18} \mathrm{O}_{5}$ & Colorless crystals & $252-253$ & [9] \\
\hline Canin (5) & $\mathrm{C}_{15} \mathrm{H}_{18} \mathrm{O}_{5}$ & Colorless crystals & $241-243$ & [9] \\
\hline Anolide (6) & $\mathrm{C}_{15} \mathrm{H}_{18} \mathrm{O}_{5}$ & Colorless crystalline substance & $167-169$ & [10] \\
\hline Tanapartin- $\beta$-peroxide (7) & $\mathrm{C}_{15} \mathrm{H}_{18} \mathrm{O}_{5}$ & Colorless crystals & 117 & {$[12]$} \\
\hline Acetyleucanbin (8) & $\mathrm{C}_{30} \mathrm{H}_{50} \mathrm{O}_{2}$ & Crystalline substance & $210-212$ & [11] \\
\hline $\begin{array}{l}\text { 3,5-Dihydroxy-6,7,8- } \\
\text { trimethoxyflavone (9) }\end{array}$ & $\mathrm{C}_{18} \mathrm{H}_{16} \mathrm{O}_{7}$ & Yellow crystalline substance & $148-150$ & {$[8]$} \\
\hline $\begin{array}{l}\text { 5-Hydroxy-3,6,7,4'- } \\
\text { tetramethoxyflavone (10) }\end{array}$ & $\mathrm{C}_{19} \mathrm{H}_{18} \mathrm{O}_{7}$ & Pale yellow crystals & $168-170$ & {$[12]$} \\
\hline $\begin{array}{l}\text { 5,3'-Dihydroxy-3,6,7,4'- } \\
\text { tetramethoxyflavone (11) }\end{array}$ & $\mathrm{C}_{19} \mathrm{H}_{18} \mathrm{O}_{8}$ & Pale yellow crystals & $182-185$ & - \\
\hline
\end{tabular}


The essential oil of Achillea L. species has antimicrobial and antibacterial action [13], its antiparasitic properties have been reported in [2].

The available literature data allow us to conclude that the component composition of $A$. nobilis L. essential oil is significantly depends on soil and climatic factors in the places of its growth, on the phase of the growing season and on the method of its extraction from plant raw materials [13]. Thus, the essential oil of A. nobilis L. from Yugoslavia is distinguished by a high content of $\alpha$-thujone $(25.7 \%)$, artemisia ketone (14.8\%), borneol (9.9\%) and camphor (8.2\%) [14]. The Kazakhstan species of A. nobilis L. contain camphor (17\%), 1,8-cineole (15.6\%), terpinen-4-ol (10\%), borneol (7.1\%) and $\beta$-eudesmol (7.1\%) [15]. There are more $\gamma$-cadinene $(46.7 \%), \alpha$-cadinol $(8.6 \%)$ and 1,8 -cineole $(5.9 \%)$ in essential oil from the Russian species of $A$. nobilis L. [16]. Italian raw materials of $A$. nobilis L. contain germacrene D (46\%), caryophyllene oxide (4.3\%), monoterpene acetate (3.9\%) and camphor (3.3\%) [17]. Essential oil of A. nobilis L. from Hungary is characterized by a high content of camphor, borneol and piperitone [18]. Two subspecies of $A$. nobilis subsp. sipylea and $A$. nobilis subsp. neilreich are growing on the territory of Turkey. Fragranol (19.3\%), 1,8-cineole (12-17\%), chrysanthenone (4-17\%), linalool (5-16\%) are the dominant components of the essential oil in them [19].

Extraction with chloroform, ethanol, diethyl ether, hot water is a relatively common and affordable method for isolation of terpenoids, flavonoids and other polyfunctional compounds from Achillea L. raw materials.

The method of sesquiterpene lactones estafiatin (1), hanphyllin (2), anobin (3) and flavonoid 3,5-dihydroxy-6,7,8-trimethoxyflavone (9) isolation from $A$. nobilis L. includes the extraction of raw materials of anthodium and leaves of $A$. nobilis $\mathrm{L}$. by chloroform. Then the chloroform extract is concentrated, dissolved in $95 \%$ ethyl alcohol and diluted with hot water in 2:1 ratio. After a day, the precipitate is filtered off; the filtrate is treated several times with chloroform. The sum of extractive substances obtained after removal of chloroform is chromatographed on macroporous silica gel (KSK grade) at a total material - sorbent ratio of $1: 15$. The column is eluted first with benzene, then successively with benzene-ether $(4: 1,3: 2$, and 1:1), ether, mixture of ether-ethyl acetate $(3: 2,1: 1)$ and ethyl acetate [8].

The following compounds were isolated as a result of chromatographic separation of the chloroform extract of A. nobilis L.: anobin (3) was isolated from benzene fractions; estafiatin (1) was isolated from benzene-ether (4:1) fractions; hanphyllin (2) was isolated from benzene-ether (1:1) fractions; 3,5-dihydroxy6,7,8-trimethoxyflavone (9) was isolated when the column was eluted with a mixture of ether-ethyl acetate $(1: 1)[8,20]$.

Chromatography of the sum of extractive substances of the chloroform extract of Achillea nobilis L. (aerial part, collection in the vicinity of Karaganda, 2016) was obtained on macroporous silica gel (KSK grade) with a gradient elution with a mixture of petroleum ether - ethyl acetate (100:0 $\rightarrow 0: 100)$. This solvent mixture is less toxic and less flammable than mixture of benzene-ether. As a result of chromatographic separation, compounds (1), (2), (9), and (11) were isolated. Compounds (11) identified based on its spectral data [21] as flavonoid 5,3'-dihydroxy-3,6,7,4'-tetramethoxyflavone was isolated from Achillea nobilis L. for the first time. The yield of (11) was $0.01 \%$ for air-dry raw materials.

Method of K.S. Rybalko [22] for the isolation from A. nobilis L. of sesquiterpene lactones chrysartemine A (5), canin (6) and anolide (7) included the extraction of A. nobilis L. flower heads and leaves by hot water $\left(80-85^{\circ} \mathrm{C}\right)$ for 1 hour, followed by treatment of the aqueous extract with chloroform. The syrup-like residue obtained after removal of chloroform was chromatographed on macroporous silica gel (KSK grade) at a total material to sorbent ratio of 1:22. Firstly the column was eluted with ether, then with a mixture of hexane-ethyl acetate $(19: 1)[9,10]$. As a result of chromatographic separation of an aqueous extract [10], sesquiterpene lactones anolide (6) from ether fractions, chrysartemine A (4) and canin (5) from hexane-ethyl acetate (19:1) fractions were isolated [9].

Isolation of the steroid acetyleucanbine $(\mathbf{8})$ from A. nobilis L. was carried out by three-fold extraction of finely ground aerial parts of $A$. nobilis L, collected during the mass flowering period, with $96 \%$ ethanol at room temperature for 3 days and by chromatographic separation of the sum of extractive substances on neutral aluminum oxide (III-IV degree of activity according to Brockmann). Firstly the column was eluted with hexane, then with a mixture of hexane-benzene, benzene, a mixture of benzene-chloroform, chloroform and a mixture of chloroform-alcohol $[11,23]$. As a result of chromatographic separation of the ethanol extract, the steroid acetyleucanbin was isolated from hexane fractions (11).

Kastner et al. [12] carried out the extraction of air-dried flower heads of A. nobilis L. with diethyl ether. The resulting extract gave a positive reaction to the peroxides presence in it. After removal of the solvent, the 
residue was extracted with $50 \%$ methanol and further purified by column chromatography and HPLC. As a result, the guaian endoperoxide tanapartin- $\beta$-peroxide (7) and the flavonoid aglycone 5-hydroxy-3,6,7,4'tetramethoxyflavone (10) were isolated.

\section{Biological activity of secondary metabolites of Achillea nobilis $L$.}

Based on the results of biological screenings, the presence of a wide spectrum of biological activity was determined both for the sums of extractive substances from A. nobilis L. and for individual compounds isolated from them.

Antimicrobial action of essential oils of A. nobilis subsp. sipylea and A. nobilis subsp. neilreichii collected in Turkey was studied on gram-positive and gram-negative bacterial strains as well as on the yeast Candida albicans $[13,19]$. It was found that samples of $A$. nobilis L. essential oils significantly inhibit the growth of all tested microorganisms, except for Pseudomonas aeruginosa.

The authors of work [24] found that samples of essential oils from 16 species of Achillea L. have moderate anticholinesterase and antimicrobial effects. At the same time, the essential oil of $A$. nobilis subsp. neilreichii differs in composition from all others. The oils from Achillea nobilis L. exhibited moderate antimicrobial activities on Fusarium verticillioides (MIC $=0.60 \mathrm{mg} / \mathrm{mL}$ ) and Fusarium graminearum $(\mathrm{MIC}=0.60-1.20 \mathrm{mg} / \mathrm{mL})$, respectively [25].

Sesquiterpene lactones of the guaian structure estafiatin (1) and anobin (3) have a pronounced antitumor activity [20]. A pronounced growth-regulating activity was found for estafiatin (1), while anolide (6) was found to have insecticidal activity [8]. Germacranolide hanphyllin (2) effectively inhibits the growth of Guerin's carcinoma, alveolar liver cancer and Pliss lymphosarcoma [20].

In the work [26], the antioxidant and antimicrobial activities of 15 extracts of $A$. nobilis L., obtained by 3 extraction methods (maceration, extraction in a Soxhlet apparatus and using ultrasonic radiation) with the use of 5 organic solvents (hexane, chloroform, ethyl acetate, ethanol and $50 \%$ aqueous ethanol) were studied. Ethanol and ethyl acetate extracts showed a relatively pronounced antioxidant activity, for which a higher content of phenolic components was noted.

The antispasmodic effect of a lyophilized ethanol extract of $A$. nobilis L. subsp. sipylea (O. Schwarz) Bassler in rat duodenum, associated with suppression of calcium influx was established [27].

In the work [28], the antinociceptive and anti-inflammatory effects of ethanol extract of A. nobilis subsp. neilreichii (Kerner) Formanek flower heads were first studied on mice and rats; its acute toxicity was determined. The authors found that the anti-inflammatory effect of the lyophilized extract is manifested at doses much lower than $\mathrm{LC}_{50}=4456 \mathrm{mg} / \mathrm{kg}$ in mice and is due to the synergistic effect of all its flavonoid components and is promising for therapeutic use.

The authors of the work [29] found that methanol extracts of six studied Achillea L. species demonstrate antiglycative, antioxidant and antimicrobial potential. At the same time, the A. pachycephalla Rech.f. and $A$. nobilis L. extracts, which are comparatively rich in polyphenolic components, showed a noticeable antiglycant ability in the bovine serum albumin (BSA)/methylglyoxal (MG) system. In work [30], a relatively high antioxidant activity of $A$. nobilis L. extracts grown under drought conditions was established, and it was noted that the total content of polyphenolic components in plant extracts growing under these conditions is significantly higher.

\section{Conclusions}

Thus, the analysis of the available literature data and the results of our own studies indicates that Achillea nobilis L. is a promising source of various classes of biologically active compounds, the most important of which are terpenoids of essential oil, sesquiterpene lactones and flavonoids, which determine the pharmacological action of its extracts. The component composition of the essential oil of Achillea nobilis L. largely depends on the soil and climatic factors in the places of its growth, the phase of the growing season, the method of its extraction from plant raw materials, and the extractant used (chloroform, ethanol, hot water, diethyl ether). Antibacterial, antimicrobial, antioxidant, antiparasitic activities are characteristic both for the sums of extractive substances from Achillea nobilis L. and for individual compounds isolated from them. Therefore, the search for biologically active components and the development of effective methods for their isolation from Achillea nobilis L. is relevant for the creation of new drugs with antibacterial, antimicrobial, antioxidant, antiparasitic action.

This research has been funded by the Science Committee of the Ministry of Education and Science of the Republic of Kazakhstan (Grant No. AP08052928). 


\section{References}

1 Сербин А.Г. Химический состав и лечебное применение видов Achillea L. / А.Г. Сербин, Л.С. Кармазова, Н.М. Ткаченко // Растительные ресурсы. - 1987. — Т. 23, Вып. 2. - С. 275-286.

2 Мамедов Э. Применение антигельминтных растений при гельминтозах домашних водоплавающих птиц / Э. Мамедов, К. Байрамова // Sciences of Europe. - 2019. — № 38. - C. 63-65.

3 Коновалов Д.А. Природные азулены / Д.А. Коновалов // Растительные ресурсы. - 1995. - Т. 31, Вып. 1. - С. $101-132$.

4 Ханин М.Л. Фитонцидные свойства экстрактов, извлеченных сжиженным углекислым газом из пряно-вкусового и лекарственно-ароматического растительного сырья / М.Л. Ханин, А.Ф. Прокопчук, Т.В. Перова, Л.А. Николаева // Фитонциды: экспериментальные исследования, вопросы теории и практики. — Киев: Наук. думка, 1975. — С. 141-143.

5 French K.E. Plant-Based Solutions to Global Livestock Anthelmintic Resistance / K.E. French // Ethnobiology Letters. 2018. — Vol. 9, No. 2. — P. 110-123. DOI: 10.14237/eb1.9.2.2018.980.

6 Buza V. In vitro anthelmintic activity assessment of six medicinal plant aqueous extracts against donkey strongyles / V. Buza, L. Cătană, S.M. Andrei, L.C. Ștefănuț, Ș. Răileanu, M.C. Matei, I. Vlasiuc, M. Cernea // Journal of Helminthology. 2020. — Vol. 94. — e147. DOI: 10.1017/s0022149x20000310.

7 Флора Казахстана / под ред. Н.В. Павлова. - Алма-Ата: Наука, 1966. — 639 с.

8 Adekenov S.M. A chemical investigation of Achillea nobilis / S.M. Adekenov, M.N. Mukhametzhanov, A.D. Kagarlitskii, A.Zh. Turmukhambetov // Chem. Nat. Compd. — 1984. - Vol. 20, No. 5. — P. 568-571. DOI: 10.1007/BF00580067.

9 Turmukhambetov A.Zh. Chrysartemin A and canin from Achillea nobilis / A.Zh. Turmukhambetov, G.K. Buketova, N.M. Gafurov, S.M. Adekenov // Chem. Nat. Compd. — 1999. — Vol. 35, No. 1. — P. 102. DOI: 10.1007/BF02238225.

10 Trudybekov K.M. Anolide - A new guaianolide from Achillea nobilis / K.M. Trudybekov, A.Zh. Turmukhambetov, S.M. Adekenov, Yu.T. Struchkov // Chem. Nat. Compd. — 1994. — Vol. 30, No. 4. — P. 460-463. DOI: 10.1007/BF00630399.

11 Serkerov S.V. Detection of acetyleucanbin in Achillea nobilis / S.V. Serkerov, S.J. Mustafaeva // Chem. Nat. Compd. 2010. — Vol. 46, No. 4. — P. 666. DOI: 10.1007/s10600-010-9709-z.

12 Kastner U. Guaianolide-endoperoxide and monoterpene-hydroperoxides from Achillea nobilis / U. Kastner, J. Breuer, S. Glasl, A. Baumann, W. Robien, J. Jurenitsch, G. Rucker, W. Kubelka // Planta medica. — 1995. — Vol. 61. — P. 83-85. DOI: 10.1055/s-2006-958010.

13 Ozdemir F.A. Potential Effects of Essential Oil Compositions on Antibacterial Activities of Achillea nobilis L. subsp. neilreichii / F.A. Ozdemir // Journal of Essential Oil-Bearing Plants. — 2019. — Vol. 22, No. 2. — P. 574-580. DOI: 10.1080/0972060X.2019.1623722.

14 Palic R. Composition and antibacterial activity of Achillea crithmifolia and Achillea nobilis essential oils / R. Palic, G. Stojanovic, T. Naskovic, N. Ranelovic // J. Essent. Oil Res. - 2003. - Vol. 15. - P. 434-437. DOI: 10.1080/10412905.2003.9698632.

15 Suleimenov Ye.M. Essential oil composition of three species of Achillea from Kazakhstan / Ye.M. Suleimenov, G.A. Atazhanova, T. Ozek, B. Demirci, A.T. Kulyyasov, S.M. Adekenov, K.H.C. Baser // Chem. Nat. Comp. — 2001. — Vol. 37, No. 5. - P. 381-384. DOI: 10.1023/A:1014471326724.

16 Калинкина Г.И. Химический состав эфирных масел некоторых видов тысячелистника флоры Сибири / Г.И. Калинкина, А.Д. Дембицкий, Т.П. Березовская // Химия растительного сырья. — 2000. — № 3. — C. 13-18.

17 Maffei M. Essential oils and chromosome numbers from Italian Achillea species / Maffei M., Chialva F., Codignola A. // J. Essent. Oil Res. — 1989. — Vol. 2. — P. 57-64. DOI: 10.1080/10412905.1993.9698171.

18 Héthelyi E. Phytochemical studies on the essential oils of species belonging to the Achillea genus by gas chromatography/mass spectrometry / E. Héthelyi, B. Dános, P. Tétényi // Biomedical \& Environmental Mass Spectrometry. — 1989. — Vol. 18. - P. 629-636. DOI: 10.1002/bms.1200180821.

19 Karamenderes C. Composition and antimicrobial activity of the essential oils of Achillea nobilis L. subsp. sipylea and subsp. neilreichii / C. Karamenderes, N.U. Karabay-Yavasoglu, U. Zeybek // Chem. Nat. Comp. — 2007. — Vol. 43, No. 5. — P. $632-634$. DOI: $10.1007 / \mathrm{s} 10600-007-0213-\mathrm{z}$.

20 Адекенов С.М. Сесквитерпеновые лактоны растений Казахстана. Строение, свойства и применение: дис. ... д-ра хим. наук: 02.00.10 - «Биоорганическая химия» / Адекенов Сергазы Мынжасарович. — М., 1992. — 385 с.

21 Han X. Isolation of high-purity casticin from Artemisia annua L. by high-speed counter-current chromatography / X. Han, X. Ma, T. Zhang, Y. Zhang, Q. Liu, Y. Ito // Journal of chromatography. — 2007. — Vol. 1151. - P. 180-182. DOI: 10.1016/j.chroma.2007.02.105.

22 Рыбалко К.С. Природные сесквитерпеновые лактоны / К.С. Рыбалко. - М.: Медицина, 1978. - 320 с.

23 Серкеров С.В. Новый компонент Achillea filipendulina Lam. / С.В. Серкеров, С.Дж. Мустафаева // Химия растительного сырья. - 2009. - № 2. - C. 101-103.

24 Yener I. A detailed biological and chemical investigation of 16 Achillea species' essential oils via chemometric approach / I. Yener, M.A. Yilmaz, O.T. Olmez, M. Akdeniz, F. Tekin, N. Hasimi, ... Ertas A.// Chemistry \& Biodiversity. — 2020. — Vol. 17, No. 3. - e1900484. DOI: 10.1002/cbdv.201900484.

25 Sampietro D.A. Chemical composition and antifungal activity of essential oils from medicinal plants of Kazakhstan / D.A. Sampietro, A. de los A. Gomez, C.M. Jimenez, E.F. Lizarraga, Z.A. Ibatayev, Y.M. Suleimen, C.A. Catalán // Natural Product Research. — 2016. — Vol. 31, No. 12. — P. 1464-1467. DOI: 10.1080/14786419.2016.1258560. 
26 Taşkın D. Phenolic composition and biological properties of Achillea nobilis L. subsp. neilreichii (Kerner) Formanek, / D. Taşkın, T. Taşkın, E. Rayaman // Industrial Crops \& Products. - 2018. - Vol. 111. - P. 555-562. DOI: 10.1016/j.indcrop.2017.11.022.

27 Karamenderes C. Antispasmodic effect of Achillea nobilis L. subsp. sipylea (O. Schwarz) Bassler on the rat isolated duodenum / C. Karamenderes, S. Apaydin // Journal of Ethnopharmacology. — 2003. — Vol. 84. — P. 175-179. DOI: 10.1016/s03788741(02)00296-9.

28 Karabay-Yavasoglu N.U. Antinociceptive and anti-inflammatory activities and acute toxicity of Achillea nobilis subsp. neilreichii extract in mice and rats / N.U. Karabay-Yavasoglu, C. Karamenderes, S. Baykan, S. Apaydin // Pharmaceutical Biology. — 2007. - Vol. 45, No. 2. - P. 162-168. DOI: 10.1155/2015/972827.

29 Afshari M. Variation in polyphenolic profiles, antioxidant and antimicrobial activity of different Achillea species as natural sources of antiglycative compounds / M. Afshari, M. Rahimmalek, M. Miroliaei // Chemistry \& Biodiversity. — 2018. — Vol. 15, No. 8. - e1800075. DOI: $10.1002 /$ cbdv.201800075.

30 Gharibi S. Effect of drought stress on total phenolic, lipid peroxidation, and antioxidant activity of Achillea species / S. Gharibi, B.E.S. Tabatabaei, G. Saeidi, S.A.H. Goli // Applied Biochemistry and Biotechnology. — 2015. — Vol. 178, No. 4. — P. 796-809. DOI: 10.1007/s12010-015-1909-3.

\title{
А.С. Кішкентаева, С.Н. Мантлер, М.М. Жақанов, С.М. Әдекенов
}

\section{Achillea nobilis L. биологиялық белсенді заттары}

\begin{abstract}
Шолу мақалада кербез мыңжапырақтың (Achillea nobilis L.) биологиялық белсенді қосылыстары және оларды бөліп алу әдістері туралы мәліметтер жалпыланған. Әр түрлі өсу орындарында жиналған Achillea nobilis L. өсімдігінен негізгі компоненттері монотерпенді қосылыстар болып табылатын эфир майы; сесквитерпенді лактондар: эстафиатин, ханфиллин, анобин, хризартемин А, канин, анолид пен танапартин- $\beta$-пероксид; ацетилэуканбин стероиды; флавоноидтар: 3,5 -дигидрокси-6,7,8-триметоксифлавон, 5-гидрокси-3,6,7,4'-тетраметоксифлавон, 5,3'-дигидрокси-3,6,7,4'-тетраметоксифлавон бөліп алынған. Кербез мыңжапырақ эфир майының компоненттік құрамы көбінесе оның өсу орындарындағы топырақ-климаттық факторларға, вегетациялық кезеңнің фазасына және оны өсімдік шикізатынан шығарып алу тәсіліне байланысты, ал сесквитерпенді лактондарды бөліп алуға қолданылатын экстрагент (хлороформ, этанол, ыстық су, диэтил эфирі) айтарлықтай әсер ететіні анықталды. Бактерияға, микробқа қарсы, антиоксидантты, паразитке қарсы белсенділік Achillea nobilis L. сығынды заттарының сомасына және олардан бөліп алынған жеке қосылыстарға да тән. Жаңа дәрілік препараттардың субстанцияларын жасау үшін кербез мыңжапырақтан биологиялық белсенді заттарды бөліп алу әдістері сипатталған. Бұл жұмыстың негізгі мақсаты - Achillea nobilis L. фитохимиялық зерттеу нәтижелерін салыстырмалы талдау.
\end{abstract}

Kiлm сөздер: Asteraceae, Achillea nobilis L., сесквитерпенді лактондар, эфир майы, флавоноидтар, бөліп алу әдістері, биологиялық белсенділік.

\section{А.С. Кишкентаева, С.Н. Мантлер, М.М. Жаканов, С.М. Адекенов}

\section{Биологически активные вещества Achillea nobilis L.}

В обзорной статье обобщены данные о биологически активных соединениях тысячелистника благородного (Achillea nobilis L.) и методах их выделения. Из Achillea nobilis L., собранного в разных местах произрастания, выделено эфирное масло, основными компонентами которого являются монотерпеновые соединения; сесквитерпеновые лактоны: эстафиатин, ханфиллин, анобин, хризартемин А, канин, анолид и танапартин- $\beta$-пероксид; стероид ацетилэуканбин; флавоноиды: 3,5 -дигидрокси- $6,7,8$ триметоксифлавон, 5-гидрокси-3,6,7,4'-тетраметоксифлавон, 5,3'-дигидрокси-3,6,7,4'-тетраметоксифлавон. Определено, что компонентный состав эфирного масла тысячелистника благородного во многом зависит от почвенно-климатических факторов в местах его произрастания, фазы вегетационного периода и способа его извлечения из растительного сырья, а на выделение сесквитерпеновых лактонов значительное влияние оказывает используемый экстрагент (хлороформ, этанол, горячая вода, диэтиловый эфир). Антибактериальная, противомикробная, антиоксидантная, противопаразитарная активность характерна как для сумм экстрактивных веществ из Achillea nobilis L., так и для выделенных из них индивидуальных соединений. Описаны методы выделения биологически активных веществ из тысячелистника благородного для разработки субстанций новых лекарственных препаратов. Основная цель данной работы - сравнительный анализ имеющихся результатов исследований по фитохимическому изучению Achillea nobilis L.

Ключевые слова: Asteraceae, Achillea nobilis L., сесквитерпеновые лактоны, эфирное масло, флавоноиды, методы выделения, биологическая активность. 


\section{References}

1 Serbin, A.G., Karmazova, L.S., \& Tkachenko, N.M. (1987). Khimicheskii sostav i lechebnoe primenenie vidov Achillea L. [Chemical composition and medicinal use of species Achillea L.]. Rastitelnye resursy - Plant resources, 23, 2, $275-286$ [in Russian].

2 Mamedov, E., \& Bairamova, K. (2019). Primenenie antihelmintnykh rastenii pri helmintozakh domashnikh vodoplavaiushchikh ptits [The use of anthelmintic plants for helminthiasis of domestic waterfowl]. Sciences of Europe, 38, $63-65$ [in Russian].

3 Konovalov, D.A. (1995). Prirodnye azuleny [Natural Azulenes]. Rastitelnye resursy - Plant resources, 31, 1, 101-132 [in Russian].

4 Khanin, M.L., Prokopchuk, A.F., Perova, T.V., \& Nikolaeva, L.A. (1975). Fitontsidnye svoistva ekstraktov, izvlechennykh szhizhennym uhlekislym hazom iz priano-vkusovoho i lekarstvenno-aromaticheskoho rastitelnoho syria [Phytoncides properties of extracts isolated with liquefied carbon dioxide from spicy-flavoring and medicinal-aromatic plant raw materials]. Fitontsidy: eksperimentalnye issledovaniia, voprosy teorii i praktiki - Phytoncides: Experimental research, theory and practice questions. Kiev: Naukova dumka [in Russian].

5 French, K.E. (2018). Plant-Based Solutions to Global Livestock Anthelmintic Resistance. Ethnobiology Letters, 9(2), 110 123. DOI: $10.14237 / \mathrm{ebl}$.9.2.2018.980.

6 Buza, V., Cătană, L., Andrei, S.M., Ștefănuț, L.C., Răileanu, S.., \& Matei, M.C., et al. (2020). In vitro anthelmintic activity assessment of six medicinal plant aqueous extracts against donkey strongyles. Journal of Helminthology, 94, e147. DOI: $10.1017 / \mathrm{s} 0022149 \times 20000310$

7 Pavlov, N.V. (1966). Flora Kazakhstana [Flora of Kazakhstan]. (Vol. 9). Alma-Ata: Nauka [in Russian].

8 Adekenov, S.M., Mukhametzhanov, M.N., Kagarlitskii, A.D., \& Turmukhambetov, A.Zh. (1984). A chemical investigation of Achillea nobilis. Chem. Nat. Compd., 20(5), 568-571. DOI: 10.1007/BF00580067.

9 Turmukhambetov, A.Zh., Buketova, G.K., Gafurov, N.M., \& Adekenov, S.M. (1999). Chrysartemin A and canin from Achillea nobilis. Chem. Nat. Compd., 35(1), 102. DOI: 10.1007/BF02238225.

10 Trudybekov, K.M., Turmukhambetov, A.Zh., Adekenov, S.M., \& Struchkov, Yu.T. (1994). Anolide — A new guaianolide from Achillea nobilis. Chem. Nat. Compd., 30(4), 460-463. DOI: 10.1007/BF00630399.

11 Serkerov, S.V., Mustafaeva, S.J. (2010). Detection of acetyleucanbin in Achillea nobilis. Chem. Nat. Compd., $46(4), 666$. DOI: $10.1007 / \mathrm{s} 10600-010-9709-\mathrm{z}$.

12 Kastner, U., Breuer, J., Glasl, S., Baumann, A., Robien, W., \& Jurenitsch J., et al. (1995). Guaianolide-endoperoxide and monoterpene-hydroperoxides from Achillea nobilis. Planta medica, 61, 83-85. DOI: 10.1055/s-2006-958010.

13 Ozdemir, F.A. (2019). Potential effects of essential oil compositions on antibacterial activities of Achillea nobilis L. subsp. neilreichii. Journal of Essential Oil-Bearing Plants, 22(2), 574-580. DOI: 10.1080/0972060X.2019.1623722.

14 Palic, R., Stojanovic, G., Naskovic, T., \& Ranelovic, N. (2003). Composition and antibacterial activity of Achillea crithmifolia and Achillea nobilis essential oils. J. Essent. Oil Res., 15, 434-437. DOI: 10.1080/10412905.2003.9698632.

15 Suleimenov, Ye.M., Atazhanova, G.A., Ozek, T., Demirci, B., Kulyyasov, A.T., Adekenov, S.M., \& Baser K.H.C. (2001). Essential oil composition of three species of Achillea from Kazakhstan. Chem. Nat. Comp., 37(5), 381-384. DOI: 10.1023/A:1014471326724.

16 Kalinkina, G.I., Dembitsky, A.D., \& Berezovskaya, T.P. (2000). Khimicheskii sostav efirnykh masel nekotorykh vidov tysiachelistnika flory Sibiri [Chemical composition of essential oils of some species of yarrow of the flora of Siberia]. Khimiia rastitelnoho syria - Chemistry of plant raw materials, 3, 13-18 [in Russian].

17 Maffei, M., Chialva, F., \& Codignola, A. (1989). Essential oils and chromosome numbers from Italian Achillea species. J. Essent. Oil Res., 2, 57-64. DOI: 10.1080/10412905.1993.9698171.

18 Héthelyi, E., Dános, B., \& Tétényi, P. (1989). Phytochemical studies on the essential oils of species belonging to the Achillea genus by gas chromatography/mass spectrometry. Biomedical \& Environmental Mass Spectrometry, 18, 629-636. DOI: 10.1002/bms. 1200180821 .

19 Karamenderes, C., Karabay Yavasoglu, N.U., \& Zeybek, U. (2007). Composition and antimicrobial activity of the essential oils of Achillea nobilis L. subsp. sipylea and subsp. neilreichii. Chem. Nat. Comp., 43(5), 632-634. DOI: 10.1007/s10600-0070213-z.

20 Adekenov, S.M. (1992). Seskviterpenovye laktony rastenii Kazakhstana. Stroenie, svoistva i primenenie [Sesquiterpene lactones of plants in Kazakhstan. Structure, properties and application]. Doctor's thesis. Moscow [in Russian].

21 Han, X., Ma, X., Zhang, T., Zhang, Y., Liu, Q., \& Ito, Y. (2007). Isolation of high-purity casticin from Artemisia annua L. by high-speed counter-current chromatograph. Journal of chromatography, 1151, 180-182. DOI: 10.1016/j.chroma.2007.02.105.

22 Rybalko, K.S. (1978). Prirodnye seskviterpenovye laktony [Natural sesquiterpene lactones]. Moscow: Meditsina [in Russian].

23 Serkerov, S.V., \& Mustafaeva, S.J. (2009). Novyi komponent Achillea filipendulina Lam. [New ingredient Achillea filipendulina Lam.]. Khimiia rastitelnoho syria - Chemistry of plant raw materials, 2, 101-103 [in Russian].

24 Yener, I., Yilmaz, M.A., Olmez, O. T., Akdeniz, M., Tekin, F., \& Hasimi N., et al. (2020). A detailed biological and chemical investigation of 16 Achillea species' essential oils via chemometric approach. Chemistry \& Biodiversity, 17(3), e1900484. DOI: $10.1002 /$ cbdv.201900484 
25 Sampietro, D.A., Gomez, A. de los A., Jimenez, C.M., Lizarraga, E.F., Ibatayev, Z.A., Suleimen, Y.M., \& Catalán, C.A. (2016). Chemical composition and antifungal activity of essential oils from medicinal plants of Kazakhstan. Natural Product Research, 31(12), 1464-1467. DOI: 10.1080/14786419.2016.1258560.

26 Taşkın, D., Taşkın, T., \& Rayaman, E. (2018). Phenolic composition and biological properties of Achillea nobilis L. subsp. neilreichii (Kerner) Formanek. Industrial Crops \& Products, 111, 555-562. DOI: 10.1016/j.indcrop.2017.11.022.

27 Karamenderes, C., Apaydin, S. (2003). Antispasmodic effect of Achillea nobilis L. subsp. sipylea (O. Schwarz) Bassler on the rat isolated duodenum. Journal of Ethnopharmacology, 84, 175-179. DOI: 10.1016/s0378-8741(02)00296-9.

28 Karabay-Yavasoglu, N.U., Karamenderes, C., Baykan, S., \& Apaydin, S. (2007). Antinociceptive and anti-inflammatory activities and acute toxicity of Achillea nobilis subsp. neilreichii extract in mice and rats. Pharmaceutical Biology, 45(2), $162-168$. DOI: $10.1155 / 2015 / 972827$

29 Gharibi, S., Tabatabaei, B.E.S., Saeidi, G., \& Goli, S.A.H. (2015). Effect of drought stress on total phenolic, lipid peroxidation, and antioxidant activity of Achillea species. Applied Biochemistry and Biotechnology, 178(4), 796-809. DOI: 10.1007/s12010015-1909-3.

30 Afshari, M., Rahimmalek, M., \& Miroliaei, M. (2018). Variation in polyphenolic profiles, antioxidant and antimicrobial activity of different Achillea species as natural sources of antiglycative compounds. Chemistry \& Biodiversity, 15(8), e1800075. DOI: $10.1002 / \mathrm{cbdv} .201800075$

\section{Information about authors}

Kishkentayeva, Anarkul Serikovna - PhD, Senior Researcher, JSC "International Research and Production Holding "Phytochemistry", M. Gazaliev street, 4, 100009, Karaganda, Kazakhstan; e-mail: a.kishkentayeva@phyto.kz; https://orcid.org/0000-0002-9169-3492.

Mantler, Svetlana Nikolaevna - Researcher, JSC "International Research and Production Holding "Phytochemistry", M. Gazaliev street, 4, 100009, Karaganda, Kazakhstan; e-mail: s.mantler@phyto.kz, https://orcid.org/0000-0002-5779-3756.

Zhakanov, Miras Mekenovich - Engineer, JSC "International Research and Production Holding "Phytochemistry", M. Gazaliev street, 4, 100009, Karaganda, Kazakhstan; e-mail: m.zhakanov@phyto.kz; https://orcid.org/0000-0001-6470-3838.

Adekenov, Sergazy Mynzhasarovich - Doctor of Chemical Sciences, General Director, JSC "International Research and Production Holding "Phytochemistry", Gazaliev str. 4, 100009, Karaganda, Kazakhstan, e-mail: arglabin@phyto.kz; https://orcid.org/0000-0001-7588-6174. 